\title{
Management of Alzheimer's Disease: Role of Existing Therapies, Traditional Medicines and New Treatment Targets
}

\author{
H. O. MALVE*
}

Department of Pharmacology and Therapeutics, Seth G. S. Medical College and K. E. M. Hospital, Parel, Mumbai-400 012, India

Malve: Pharmacotherapy of Alzheimer's Disease

\begin{abstract}
Dementia, a common problem in elderly, is rising worldwide including India. Alzheimer's disease is the main aetiology for dementia. Currently anticholinesterases, $\mathrm{N}$-methyl-D-aspartate receptor antagonists, disease modifying agents form the mainstay of treatment of Alzheimer's disease. However, recent breakthroughs in Alzheimer's disease research have given multiple new treatment targets. This review summarizes the role of existing therapies and their limitations, role of traditional medicines and new treatment targets. The newer agents include molecules targeting $\tau$-protein like modulators of $\tau$-kinases or phosphatases, kinase inhibitors, $\tau$-aggregation inhibitors. It also includes molecules, which targets amyloid plaques like inhibitors or modulators of the secretases, amyloid- $\beta$ aggregation inhibitors and amyloid-plaque degradation enhancers. Role of nootropics, statins and antipsychotics in the management of Alzheimer's disease is limited and lacks conclusive evidence. Studies with vaccines have shown reduced amyloid- $\beta$ and $\tau$-pathology, neutralized soluble amyloid beta oligomers. But search for the appropriate vaccine for Alzheimer's disease is still on. Antioxidants, metal chelators, metal-protein attenuating compounds, metal complexes have also shown some potential. Traditional medicines like huperzine A and galantamine have been used for management of Alzheimer's disease. Traditional medicinal system in India particularly Ayurveda mentions neuroprotective actions of plant drugs like Brahmi, Shankhapushpi, Amla, Guduchi, Tulsi, Ashwagandha and Haritaki, which can help in improving the treatment armamentarium for Alzheimer's disease. The understanding of Alzheimer's disease neurobiology is improving now and the search for better treatment options is still on. This provides an opportunity for more research on integrated approach using existing therapies, traditional and alternative medicines with newer treatments and potential candidates for management of Alzheimer's disease.
\end{abstract}

Key words: Ayurveda, anticholinesterases, cognition, dementia, memory, neurodegenerative disorders

Memory is the process to encode, accumulate and recall information and past experiences ${ }^{[1,2]}$. The loss of memory leads to dementia, and Alzheimer's disease (AD) is the most prevalent type of dementia, which accounts for $60-80 \%$ of cases worldwide ${ }^{[3]}$. AD is a primary neurodegenerative disease with characteristic neuropathological and neurochemical features. However, the exact aetiology of AD is still not known. Dementia in $\mathrm{AD}$ with onset before the age of $65 \mathrm{y}$ has a relatively rapid deteriorating course with marked multiple disorders of higher cortical functions and the other with onset after $65 \mathrm{y}$ has a slower progression with memory impairment as principal feature. These phases of AD progression with features were summarized in Table 1.

As per the statistics provided by the Alzheimer's disease International's World Alzheimer Report 2015, an estimated 46.8 million people are living

*Address for correspondence

E-mail: dr.harshad.malve@gmail.com

January-February 2017 with dementia worldwide. This is projected to double every $20 \mathrm{y}$ and estimated to be 131.5 million by year $2050^{[4]}$. East Asia has largest number of people with dementia ( 9.8 million), followed by Western Europe (7.4 million), South Asia (5.1 million) and North America (4.8 million). Top ten countries with highest number of people with dementia in 2015 include China (9.5 million), USA (4.2 million), India (4.1 million), Japan (3.1 million), Brazil (1.6 million), Germany (1.6 million), Russia (1.3 million), Indonesia, France and

This is an open access article distributed under the terms of the Creative Commons Attribution-NonCommercial-ShareAlike 3.0 License, which allows others to remix, tweak, and build upon the work non-commercially, as long as the author is credited and the new creations are licensed under the identical terms

Accepted 23 December 2016

Revised 26 October 2016

Received 04 June 2016

Indian J Pharm Sci 2017;79(1): 2-15 


\begin{tabular}{|c|c|}
\hline Phase & Features \\
\hline Preclinical & $\begin{array}{c}\text { Measurable changes in the biomarkers (such as brain imaging and spinal fluid chemistry) that indicate } \\
\text { the earliest signs of disease, before any symptoms are visible. }\end{array}$ \\
\hline $\begin{array}{l}\text { Mild cognitive } \\
\text { impairment }(\mathrm{MCl})\end{array}$ & $\begin{array}{l}\text { Mild changes in memory and thinking abilities, which is enough for noticing, which can be measured, } \\
\text { but no impairment of normal everyday activities and functioning. }\end{array}$ \\
\hline Dementia & Memory, behavioural and thinking symptoms which impair a person's ability to function in daily life. \\
\hline
\end{tabular}

Italy (1.2 million each $)^{[4]}$. The mortality rate as per the report is much higher in comparison to those caused by stroke, heart disease and cancer ${ }^{[4,5]}$. Epidemiological studies conducted in India between 1996 and 2006 indicated that dementia affects $2.7 \%$ of the population and $\mathrm{AD}$ being the most common cause $(1.3 \%)^{[6]}$. In the year 2010, it was reported that an estimated 3.7 million Indian people aged over 60 had dementia. A $10 \mathrm{y}$ follow-up study from South India reported higher incidence of 11.67 per 1000 person-years for those above $55 \mathrm{y}$ of age which increased with age $\mathrm{e}^{[7]}$. As per Delphi consensus study forecast, the worldwide prevalence of dementia will double between 2001 and 2040, whereas India, China, south Asian and western pacific countries expect increase in prevalence by $300 \%{ }^{[8]}$. This forecast of "AD-epidemic" represents a major health concern to most nations including India. Severe dementia from AD can cause complications like immobility, malnutrition and swallowing disorders, which significantly increase the risk of other serious conditions like aspiration pneumonia resulting to death $^{[5]}$. It can also lead to emotional and physical stress to caregivers and poor quality of life to both the patients and caregivers ${ }^{[5]}$.

Till date, there has been no effective approach in terms of cure or prevention of AD. The available pharmacological therapy with antidementia drugs is largely symptomatic, with no permanent clinical benefits on functional, behavioural and cognitive manifestations of the disease. In this context, there is an imperative need to develop newer treatment modalities with disease-modifying properties for AD. This review summarizes available treatment options for $\mathrm{AD}$ targeting different levels of pathophysiology. It also focuses on the new drugs in pipeline, potential candidates and alternative therapies. The selection of the literature was done as per the Quorom flow chart given in fig. 1.

\section{Pathophysiology:}

The name Alzheimer's is from the German neuropathologist, Prof. Alois Alzheimer, who reported this disease in the year 1906 for the first time in a 51-y-old lady affected for years by memory issues, language dysfunction and confusion ${ }^{[9]}$. It is a specific neurodegenerative disease characterized by senile deposits, neuritic twists, and gradual loss of neurons leading to memory loss, alterations in thinking and other brain functions. The progression of the disease is slow and gets worse with further neuronal cell death ${ }^{[10,11]}$. Dementia resulting from AD is characterized by a decline primarily in cortical aspects of cognition like memory, language, and praxis and is known to follow a characteristic time course of gradual onset and progression $^{[11]}$.

\section{Pathogenesis of AD:}

Amyloid plaque (AP) formation takes place as follows ${ }^{[10-12]}$. A type-I transmembrane glycoprotein, amyloid precursor protein (APP) undergoes proteolytic processing through physiologic i.e. nonamyloidogenic or an amyloidogenic pathway. In the physiologic pathway a membrane-bound enzyme, $\alpha$-secretase cleaves APP within its amyloid- $\beta$ (A $\beta)$ domain resulting in the extracellular secretion of soluble APP- $\alpha$ and production of a short, membranebound $\mathrm{COOH}$-terminal fragment (CTF), $\alpha$-CTF or C83. Subsequently $\gamma$-secretase cleaves C83 and forms an extracellular peptide termed $\mathrm{p} 3$ and release APP intracellular domain (AICD) into the cytoplasm. The amyloidogenic pathway is initiated when $\beta$-secretase cleaves APP at $\mathrm{N}$-terminal part of $\mathrm{A} \beta$ domain. This cleavage leads to the extracellular release of soluble APP- $\beta$, while $\beta$-CTF or C99 fragment remains membrane bound. Sequential $\gamma$-secretase division of C99 allows removal of AICD and secretion of $A \beta$ into the lumen or extracellular space, which aggregates to form APs.

Neurofibrillary tangles formation takes place as follows ${ }^{[10-12]}$, Tau $(\tau)$, a normal constituent of neurons associated with intracellular microtubules gets abnormally phosphorylated and deposited intracellularly as paired helical filaments. After neuronal cell death these filaments aggregate as extracellular neurofibrillary tangles. Addition of fibrillar $A \beta$ to mature hippocampal neurons results in progressive neuritic degeneration accompanied by enhanced phosphorylation of adult $\tau$-isoforms. 


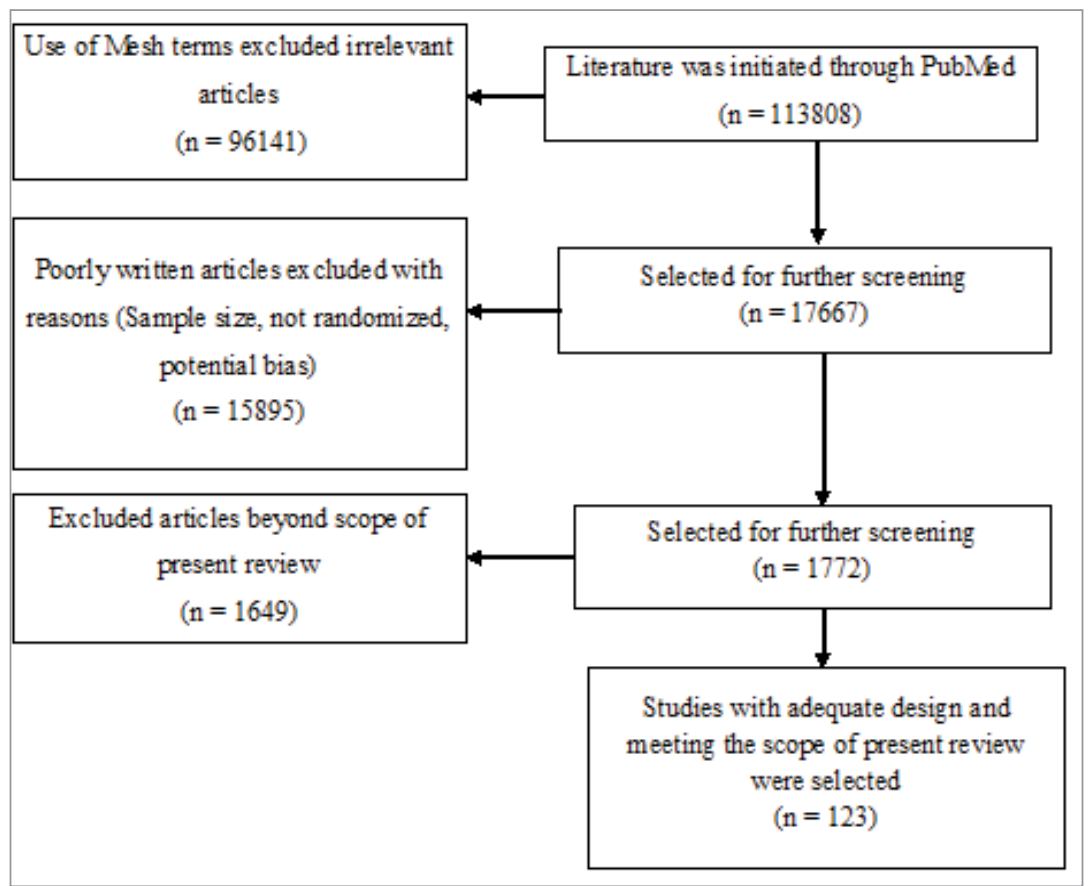

Fig. 1: Quorom flow chart

Recent studies on pathogenesis of $\mathrm{AD}$ have raised doubts over the "amyloid hypothesis"; however, none of these data state that $A \beta$ is not involved in AD. AP remained the main pathophysiology of AD. People having AP in brain without any cognitive impairment should be considered in "pre-clinical phase of AD" ${ }^{[13]}$. The AD pathophysiology involves cellular, genetic and molecular imbalances leading to DNA damage, autophagy, neuronal death and deposition of $\tau$ with $\mathrm{AP}^{[13]}$.

One more characteristic pathological feature includes change in certain metal concentrations in brain, this theory is termed as "metal hypothesis"[14]. Elevated brain iron levels and accumulation of copper and zinc is found in cerebral amyloid deposits. Both ionic zinc and copper are able to enhance the accumulation of $\mathrm{A} \beta$, the principle component of amyloid deposits. The neurotoxic redox activity of $A \beta$ is promoted by copper and iron; they also induce oxidative crosslinking of the peptide to form stable oligomers. Synaptic transmission is affected adversely by the excessive accumulation of these oligomers at synaptic $\mathrm{cleft}^{[14,15]}$.

A prospective study reported some risk factors for AD like increasing age, low educational level, and APOE4 allele ${ }^{[16]}$. Deficiency of cholinergic mechanism has been found to be associated in the cognitive and behavioural manifestations of $\mathrm{AD}^{[17,18]}$. Cardiovascular diseases like diabetes mellitus, hypertension and their risk factors such as hyperinsulinemia, hyperlipidemia, hyperhomocysteinemia and smoking have been reported as other important risk factors for $\mathrm{AD}^{[19,20]}$.

Dementia in $\mathrm{AD}$ with early onset has onset before the age of 65 with comparatively fast deterioration and with marked multiple disorders of higher cortical functions. Early onset familial AD (FAD) is hereditary with genetic predisposition; symptoms appear at early age usually $30-50 \mathrm{y}$. Onset of AD with no family history is called sporadic and has no genetic predisposition ${ }^{[21,22]}$. Dementia in $\mathrm{AD}$ with late onset has onset after the age of 65 usually in late seventies or thereafter with a slow progression with memory impairment as principal feature. There are distinct differences in clinical features, genetics and brain metabolism in familial and sporadic forms of $\mathrm{AD}^{[21,22]}$.

\section{TREATMENT}

\section{Goals of treatment:}

The main goal of treatment in patients with $\mathrm{AD}$ is to improve or at least slow loss of memory and cognition and to maintain independent function ${ }^{[23]}$. The working group guidelines recommend anticholinesterase inhibitors, N-methyl-D-aspartate (NMDA) receptor antagonist, and other medications, where clinically indicated, to treat cognitive decline in these patients ${ }^{[23]}$. Non-pharmacological approaches and referral to social service agencies or support organizations are also suggested as treatment strategy ${ }^{[24,25]}$. 


\section{Existing treatments:}

Current treatment strategies of $\mathrm{AD}$ deal with the biochemical pathway leading to the disease. The drugs in current use can be divided as those which are designed to enhance cholinergic function, those that reduce the synthesis of free radicals, antiinflammatory agents, oestrogens and a miscellaneous group of natural products $^{[24,25]}$.

\section{Drugs enhancing cholinergic function:}

Cholinesterase inhibitors (anticholinesterases or ACHEI) increase cholinergic synaptic transmission by inhibiting acetylcholinesterase enzyme in the synaptic cleft, thereby reducing the hydrolysis of acetylcholine released from presynaptic neurons. The first ACHEI approved by United States Food and Drug Administration (USFDA) for treatment of $\mathrm{AD}$ was tacrine. Tacrine and donepezil are reversible inhibitors of acetylcholinesterase that prevent enzyme-acetylcholine complex formation, whereas rivastigmine, a reversible carbamate inhibitor decreases enzyme activity directly ${ }^{[25,26]}$. Oral and transdermal formulations of rivastigmine are available. Recently published Cochrane review has shown that rivastigmine 6 to $12 \mathrm{mg}$ daily orally or $9.5 \mathrm{mg}$ daily transdermally is beneficial for management of mild to moderate $\mathrm{AD}^{[27]}$. Another review published in 2006 has shown that long-term treatment with donepezil gave benefits in cognitive function, activities of daily living and behaviour in patients of $\mathrm{AD}$ and moreover, it was better tolerated as compared to other ACHEI ${ }^{[28]}$. Rivastigmine transdermal patch $(13.3 \mathrm{mg} / 24 \mathrm{~h})$ and donepezil (10 and $23 \mathrm{mg} / \mathrm{d})$ can be used for moderate to severe $\mathrm{AD}^{[29]}$.

Recently, a systematic review assessing the riskbenefits of dementia medications concluded that ACHEI gave moderate improvement in cognitive, functional, and global benefits to patients with mild to moderate $\mathrm{AD}$, however, the clinical significance of these effects are unclear ${ }^{[30]}$. Also, long-term efficacy of ACHEI is an issue as their efficacy wanes with duration of treatment. Side effects with ACHEI include weight loss, debility and syncope, which could be detrimental in elderly patients ${ }^{[30]}$.

\section{NMDA receptor antagonist:}

Memantine, a NMDA receptor antagonist, blocks overexcited NMDA receptors thereby diminishes the entry of $\mathrm{Ca}^{++}$leading to decreased glutamate release and inhibiting the processes, which lead to neurotoxicity.
Memantine blocks the voltage-dependent, lowmoderate affinity, uncompetitive NMDA receptors with fast blocking/unblocking kinetics and lowmoderate affinity inhibits effect of excessive glutamate, maintaining physiologic activation of NMDA receptors required for learning and memory ${ }^{[31]}$. It also inhibits and reverses protein phosphatase (PP)-2A inhibition-induced abnormal hyper-phosphorylation and accumulation of $\tau$. It has shown to have multiple actions, which could be beneficial in patients with AD. Its adverse effects are mild and reversible ${ }^{[32]}$. It offers minimal benefits in moderate to severe $\mathrm{AD}$ when used as a monotherapy. Combination therapy of memantine with ACHEI is considered as a treatment of choice in moderate to severe $\mathrm{AD}^{[33]}$.

\section{Role of cognition enhancers (Nootropics):}

Nootropics are the drugs to treat cognitive deficits in patients suffering from AD. But it has been reported that drugs like pramiracetam were unlikely to confer symptomatic benefit to $\mathrm{AD}$ patients ${ }^{[34]}$. Piracetam, a commonly used nootropic has been tried for management of $\mathrm{AD}$ with poor results. It has shown to slow the progression of cognitive deterioration at high-dose and long-term treatment in humans ${ }^{[35]}$. Cochrane review published in 2001 did not support the use of piracetam in management of $\mathrm{AD}^{[36]}$. Another nootropic, levetiracetam, which is commonly used as an antiepileptic, has been used as a cognitive enhancer in $\mathrm{AD}^{[37]}$. It has been reported to reverse hippocampal remodelling, synaptic dysfunction, behavioural abnormalities, deficits in learning and memory in human APP in transgenic mice ${ }^{[37]}$. More clinical data is needed to recommend its use in AD.

\section{Dimebolin (latrepirdine):}

It is an antihistaminic agent, which acts by multiple mechanisms that include blocking the action of neurotoxic $\mathrm{A} \beta$ and inhibit L-type calcium channels ${ }^{[38]}$. It also modulates the action of AMPA and NMDA glutamate receptors and blocks a novel target that involves mitochondrial pores to exert a neuroprotective effect $^{[38]}$. Studies in monkeys have reported that dimebolin is capable of improving components of working memory ${ }^{[39]}$. However, the data on dimebolin use in humans is limited with inconsistencies, bias between studies. No effect of latrepirdine was found on cognition and function in mild-to-moderate $\mathrm{AD}$ patients, though modest benefit for behaviour was seen ${ }^{[40]}$. Further research is needed to evaluate the potential benefit of latrepirdine on neuropsychiatric 
symptoms in $\mathrm{AD}$.

\section{Oestrogen:}

Postmenopausal changes have shown to induce neurodegeneration in females. Oestrogens are shown to have protective effects on hippocampal dendrites with augmentation of choline acetyl-transferase activity in experimental studies ${ }^{[4]}$. Additional properties of oestrogens, which may contribute to their neuroprotective effects include antioxidant properties and a facilitation of the processing of APP along a non-amyloidogenic pathway ${ }^{[42]}$. Oestrogen receptor $\beta$ (ER $\beta$ ) has shown to have the role in regulation of neurological health and development of AD though the therapeutic role is yet unclear as it lacks evidence in humans ${ }^{[41]}$.

\section{Role of statins in AD:}

Studies have reported that the presence of high serum cholesterol levels can lead to pathogenesis of $\mathrm{AD}^{[43]}$. This has led to the use of statins in the preventing AD. Lowering cholesterol in experimental animal models slowed the expression of Alzheimer's pathology ${ }^{[44]}$. The Rotterdam study was population-based study with 6992 participants followed up for $9 \mathrm{y}$ to study the use of statin in prevention of AD. It has reported a lower risk of $\mathrm{AD}$ with use of statins ${ }^{[45]}$. However, a Cochrane review published in 2014 has concluded that there is no benefit in symptom scores with statin treatment in dementia hence the exact potential of statins in $\mathrm{AD}$ management needs to be evaluated thoroughly ${ }^{[46]}$.

\section{Role of non-steroidal antiinflammatory drugs (NSAIDs) in AD:}

AD lesions have shown various inflammatory mediators along with activated microglia. This indicates antiinflammatory agents such as NSAIDs may protect against the disease ${ }^{[47]}$. A study conducted in Rochester, Minnesota, between 1980-84 has reported protective effects of NSAID in $\mathrm{AD}^{[48]}$. Long-term use of ibuprofen has also been reported to have a protective effect against the development of $\mathrm{AD}$ in a cohort of elderly people from US ${ }^{[49]}$. Studies have reported contrasting results from clinical trials, low-dose trial of the traditional NSAID, naproxen was reported to have failed, whereas pilot trials using therapeutically established doses of indomethacin and diclofenac/ misoprostol have reported to have shown promise in this regard ${ }^{[47]}$. Cochrane review published in 2012 has mentioned no role of aspirin, steroid and NSAIDs in management of $\mathrm{AD}^{[50]}$. A recently published review by Wang et al. has highlighted limitations of the evidence for use of NSAIDs in management of $\mathrm{AD}$, as no randomized clinical trials have supported the use of NSAID in AD, though the observation studies favours $\mathrm{it}^{[51]}$.

\section{Treatment of behavioural and psychological symptoms:}

Atypical antipsychotics have been commonly used for the treatment of psychosis, aggressive behaviour, and anxiety in patients with AD. The Clinical Antipsychotic Trials of Intervention Effectiveness-Alzheimer's Disease (CATIE-AD) study has reported the use of atypical antipsychotics namely olanzapine, quetiapine, and risperidone to worsen cognitive function in patients with $\mathrm{AD}$ compared to those on placebo ${ }^{[52]}$. Antipsychotics, anxiolytics and antidepressants are the potential source for drug interactions in management of $\mathrm{AD}$ and hence precautions needs to be taken while these drugs are used ${ }^{[53]}$.

Particularly, antipsychotic drugs have high risk of drug interactions leading to adverse events. These drugs can interfere with the progression of cognitive impairment and interact with several drugs including ACHEI ${ }^{[54]}$. Thus, non-pharmacological treatments are preferred for behavioural symptoms, which include some specific tasks or exercises ${ }^{[54]}$.

\section{Non-pharmacological treatment:}

Various non-pharmacological treatments like cognitive training, cognitive rehabilitation, and cognitive stimulation therapy (CST) have been tried with limited benefits in management of $\mathrm{AD}^{[54]}$. Cognitive rehabilitation showed functional benefits in $\mathrm{AD}$ however the clinical data is limited.

\section{Natural products:}

Extract of Ginkgo biloba, obtained from the leaves of a subtropical tree, has putative antioxidant, neurotrophic, and antiinflammatory properties. A quantitative analysis of literature published in 1998 had shown significant improvement in objective measures of cognitive function in patients suffering from $\mathrm{AD}$ on G. biloba ${ }^{[55]}$. Smith et al. have reported the suppressive effect of extract from $G$. biloba on hydrogen peroxide related reactive oxygen species in in vivo and in vitro models of $\mathrm{AD}^{[56]}$. A systematic review published in 2010 mentioned high-dose (240 mg) Ginkgo to benefit for activities of daily living. It was found to be safe 
in $\mathrm{AD}$ patients however further studies are needed to know the exact benefits it can offer in $\mathrm{AD}^{[57]}$. Impact of Cholinergic Treatment Use (ICTUS) study evaluated supplementation of $G$. biloba in 828 patients with mild to moderate $\mathrm{AD}$ receiving CHEI treatment. Ginkgo provided some added cognitive benefits in these patients however clinical benefits needed to be confirmed $^{[58]}$. Meta-analysis published in 2014 has shown that $G$. biloba may help established AD patients with cognitive symptoms but cannot prevent the neurodegenerative progression of the disease. Hence, its role in management of $\mathrm{AD}$ is questionable ${ }^{[59]}$.

The fact remains that current pharmacotherapy is not sufficient to halt the disease progression nor do they

TABLE 2: COMPOUNDS TARGETING AP FORMATION IN AD[3,14,60-70]

\begin{tabular}{|c|c|c|}
\hline Compound & Class & Current status \\
\hline Bapineuzumab & Monoclonal antibody & No improvement in clinical outcomes in 2 phase III studies \\
\hline Solanezumab & Monoclonal antibody & No statistical significance on their primary endpoints in extended phase III study. \\
\hline Ponezumab & Monoclonal antibody & Development stopped by sponsor after phase II study \\
\hline Gantenerumab & Monoclonal antibody & $\begin{array}{l}\text { No cognitive benefit compared to placebo, but evidence of efficacy in patients } \\
\text { with faster progressing disease who had higher exposure to the drug was seen in } \\
\text { phase III. Showed clear changes in biomarkers like CSF p- } \tau \text {, CSF t- } \tau \text {, Amyloid-PET. }\end{array}$ \\
\hline Aducanumab & Monoclonal antibody & Completed Phase Ib study \\
\hline $\begin{array}{l}\text { Tarenflurbil } \\
\text { (R-flurbiprofen) }\end{array}$ & $\begin{array}{l}\text { Gamma-secretase } \\
\text { modulator }\end{array}$ & $\begin{array}{l}\text { Two large phase III trials failed to show positive results due to low potency and } \\
\text { poor brain penetration. }\end{array}$ \\
\hline Semagacestat & $\begin{array}{l}\text { Gamma-secretase } \\
\text { inhibitor }\end{array}$ & $\begin{array}{l}\text { Discontinued after phase III study. No improvement in cognitive status, and } \\
\text { patients receiving the higher dose had significant worsening of functional ability. } \\
\text { Adverse event includes infection and skin cancer. }\end{array}$ \\
\hline MK-8931 & BACE1 inhibitor & Phase III study \\
\hline Avagacestat & $\begin{array}{l}\text { Gamma-secretase } \\
\text { inhibitor }\end{array}$ & $\begin{array}{l}\text { Failed to demonstrate efficacy in phase II study and was associated with adverse } \\
\text { effects like non-melanoma skin cancer, reversible renal tubule effects and } \\
\text { gastrointestinal adverse effects. }\end{array}$ \\
\hline AD1231 & $\begin{array}{l}\text { Gamma-secretase } \\
\text { inhibitor }\end{array}$ & Preclinical study \\
\hline CHF5074 & $\begin{array}{l}\mathrm{Y} \text {-secretase modulator } \\
\text { and NSAID }\end{array}$ & Phase II trial on hold \\
\hline Tramiprosate & $\begin{array}{l}\mathrm{A} \beta \text { aggregation } \\
\text { inhibitor }\end{array}$ & $\begin{array}{l}\text { Phase III clinical trial showed no statistically significant difference between } \\
\text { placebo and drug treated patients. However post-hoc analyses showed a } \\
\text { significant treatment-related reduction in hippocampus volume loss and a trend } \\
\text { towards slowing of decline on the Alzheimer Disease Assessment Scale - cognitive } \\
\text { subscale (ADAS-cog). }\end{array}$ \\
\hline Curcumin & $\begin{array}{l}\text { Antiamyloid } \\
\text { aggregator }\end{array}$ & $\begin{array}{l}\text { A Phase II study in mild to moderate AD patients was initiated in } 2003 \text { but current } \\
\text { status not known. }\end{array}$ \\
\hline & & $\begin{array}{c}\text { Another Phase II study with Curcumin formulation Longvida for moderate to } \\
\text { severe AD patients was started in } 2009 \text { in India but current status unavailable. } \\
\text { A 24-week placebo-controlled trial failed to demonstrate clinical or biochemical } \\
\text { evidence of efficacy due to limited bioavailability of orally administered Curcumin } \\
\text { compound. }\end{array}$ \\
\hline Crenezumab & Monoclonal antibody & Phase Ib study is initiated with intravenous Crenezumab in 2015. \\
\hline Gammagard & Immunoglobulin & $\begin{array}{l}\text { Phase III study of } 390 \text { patients with mild to moderate AD showed no effect on } \\
\text { slowing cognitive and functional decline. }\end{array}$ \\
\hline Colostrinin & $\begin{array}{l}\mathrm{A} \beta \text { aggregation } \\
\text { inhibitor }\end{array}$ & No clinical studies \\
\hline Davunetide & Neuropeptide & $\begin{array}{l}\text { Phase II and III studies with nasal formulation showed negative results hence no } \\
\text { further development. }\end{array}$ \\
\hline Azeliragon & $\begin{array}{c}\text { Receptor for } \\
\text { advanced glycation } \\
\text { end-products (RAGE) } \\
\text { inhibitor }\end{array}$ & A placebo controlled, 18-mon phase III trial started in 2015. \\
\hline
\end{tabular}


have any role to play in mutation of genes involved in development of AD. Therapeutic methods, which can lessen the effects of a gene mutation, or modify the effects of a gene mutation are the need of the hour and more importantly the drugs that can delay the onset and progression of the disease.

\section{New treatment strategies:}

The currently available treatment for $\mathrm{AD}$ is mainly symptomatic and offer temporary benefits on cognitive, functional and behavioural manifestations of the disease. The pharmacological basis of the same is to bring an increase in synaptic availability of acetylcholine. In such scenario, the need of the hour is an agent that will slow the progression of the neurodegenerative process thereby inhibiting critical events in the pathophysiology of neurodegeneration, and therefore, attenuating the pathological load ${ }^{[3]}$.

\section{New targets for treatments: inhibitors of AP formation and $\tau$-protein aggregation:}

Recently the focus of research has shifted to develop new drugs, which target disease modification in AD. These drugs are divided as antiamyloid agents and drugs that target other pathological pathways. Antiamyloid compounds are further subdivided into drugs designed to block or inhibit the overproduction or aggregation of $A \beta$, or to favour its clearance from the brain. Drugs that target the pathological pathways include neurotransmitter and cell-signalling agents, neuroprotective agents, glial cell modulators and $\tau$-based therapies ${ }^{[3]}$. Antiamyloid strategies consist of pharmaceutical agents with distinct mechanisms that will enable the clearance and/or inhibit the production and/or prevent the aggregation of $A \beta^{[60-63]}$. The compounds targeting amyloid pathway with their current status are summarized in Table $2^{[60-68]}$.

The novel targets in treatment of $\mathrm{AD}$ include muscarinic and nicotinic receptors, $\tau$ proteins and $\beta$-secretase enzyme ${ }^{[60-63]}$. Lithium is found to inhibit glycogen synthase kinase-3 $\beta$ (GSK-3 $\beta$ ) activity results in decreased levels of both $A \beta$ and $\tau$-phosphorylation $\tau$-aggregation and neurofibrillary tangles (NFT) formation in transgenic mice. Other GSK-3 $\beta$ inhibitors are being developed, such as AR-A014418 as well as other kinase inhibitors ${ }^{[60-62]}$. AL-108 or NAP, which is an intra-nasal formulation, derived from the biological activity-dependent neuroprotective protein secreted by brain in response to various insults. AL-108 interacts with microtubules, reduces $\tau$-hyper phosphorylation and enhances soluble $\tau$ levels leading to an improvement in cognition ${ }^{[60-68]}$. The compounds targeting $\tau$ pathology with their current status are summarized in Table 3.

\section{Strategies targeting metal ions: metal chelators and complexes:}

Metal chelators bind strongly to 2 or more metal ions and form a cyclic ring, which converts metal ions into an inert form and depletes total pool of bioavailable metals $^{[14,60,62]}$. Desferrioxamine (DFO), a Fe chelator with high binding affinities for $\mathrm{Zn}, \mathrm{Cu}$ and $\mathrm{Al}$ was the first such agent to enter clinical investigations for treatment of AD. DP-109 reduced formation of cerebral amyloid angiopathy (CAA) and deposition of APs as well as it re-solubilized A $\beta$. Modulating metals with metallo-complexes (i.e. complexes of pyrrolidinedi-thio-carbamate, PDTC and $\mathrm{Cu}$ ) is an alternative approach to chelation and serves to remove metals

TABLE 3: COMPOUNDS TARGETING TAU ${ }^{[3,14,60-70]}$

\begin{tabular}{|c|c|c|}
\hline Compound & Class & Current status \\
\hline Tideglusib & $\begin{array}{l}\text { Glycogen synthase } \\
\text { kinase } 3 \text { (GSK3) } \\
\text { inhibitor }\end{array}$ & $\begin{array}{c}\text { Completed phase II study and found to be safe at the dosage used } \\
\text { (1000 mg QD). However efficacy is yet to be seen. Long duration } \\
\text { trials with higher dose are needed. }\end{array}$ \\
\hline NP031112 & GSK3 inhibitor & Phase Ila study was initiated in 2009. Current status unavailable. \\
\hline Sodium selenite & GSK3 inhibitor & $\begin{array}{c}\text { A } 24 \mathrm{w} \text { phase lla study was initiated in 2011. Current status } \\
\text { unavailable. }\end{array}$ \\
\hline Lithium & GSK3 i & Phase II studies ongoing. \\
\hline $\begin{array}{l}\text { Epothilone D (BMS-241027) } \\
\text { Paclitaxel }\end{array}$ & $\begin{array}{l}\text { Microtubule stabilizer } \\
\text { Microtubule stabilizer }\end{array}$ & Discontinued after a phase I study ir \\
\hline TPI 287 & $\begin{array}{l}\text { Microtubule stabilizer } \\
\text { and tubulin binder }\end{array}$ & Phase I study continuing. \\
\hline $\begin{array}{l}\text { Methylthioninium chloride } \\
\left(M T C, \text { rember }^{T M}\right)\end{array}$ & $\begin{array}{l}\text { Tau aggregation } \\
\text { inhibitor }\end{array}$ & $\begin{array}{l}\text { An exploratory, dose-finding, placebo-controlled study with } \\
\text { monotherapy was conducted in } 332 \text { patients of mild to moderate AD } \\
\text { showed significant improvement in ADAS-cog. }\end{array}$ \\
\hline
\end{tabular}


from biologically deleterious sites and deliver them to areas of deficiency ${ }^{[14,60]}$. This helps in maintaining metal homeostasis. Metal-protein attenuating compounds (MPAC), have weak, reversible affinity towards metals, and thus compete with endogenous ligands for metal ions and restore normal metal levels in specific cellular compartments (clioquinol) ${ }^{[14,60]}$.

\section{Disease modifying drugs in AD:}

Recent research is directed to identify and formulate the drugs that will modify the pathological steps, which include deposition of AP, neurofibrillary tangles, oxidative damage, inflammation, iron deregulation and cholesterol metabolism ${ }^{[69,70]}$. The most studied drug in this regard is the antiamyloid aggregation agent, tramiprosate (homotaurine), a glycosaminoglycan (GAG) mimetic, which is derived from marine red algae. It has shown promising results in in vivo and in vitro studies ${ }^{[71]}$. Clinical trials are on-going to evaluate its therapeutic potential. Natural antiamyloid antibodies have been detected in human intravenous immunoglobulin (IVIG) obtained from the pooled plasma of healthy blood donors ${ }^{[72]}$. IVIG is being tested in clinical trials though the initial trial was discontinued due to severe adverse effects.

Search for the agents, which can target more than one pathology has resulted in the development of multitarget-directed ligands (MTDL) ${ }^{[73]}$. MTDL have more than one of the following actions like cholinergic action, metal chelating properties, calcium channel blocking actions, antiglutamate-induced excitotoxicity or blocking the enzymes for $A \beta$ or $\tau$ pathways. One such novel class of MTDL combining BACE1 ( $\beta$-site APP cleaving enzyme 1) inhibition with metal chelating properties has also been developed. This strategy combines two therapeutic targets and hence provides promising leads as potential treatment for $\mathrm{AD}^{[3,73]}$.

\section{Drugs which reduce the synthesis of free radicals:}

Free radicals are known to initiate neuronal death. $\alpha$-tocopherol has been found to limit free-radical formation, oxidative stress, and lipid peroxidation ${ }^{[24,74]}$. It also supports survival of cultured neurons exposed to $\beta$-amyloid protein ${ }^{[2474]}$. Monoamine oxidase inhibitor, selegiline has antioxidant properties and also increases brain catecholamines, which have been found to be effective in treatment of $\mathrm{AD}$. But the therapeutic use is not recommended due to uncertain efficacy ${ }^{[74,75]}$. Ladostigil has cholinesterase-butyrylesterase $(\mathrm{CH}-$ BUE) and brain selective monoamine-oxidase (MAO) inhibitory activities with neuroprotective actions and was tried as potential treatment of AD but it is still under development awaiting more clinical data ${ }^{[76]}$.

\section{Butyryl-cholinesterase:}

Enzyme butyryl-cholinesterase (BCHE), like ACHE, co-regulates metabolism of the acetylcholine, which is an important neurotransmitter for cognitive functions. BCHE is mainly expressed in white matter, glia and in neuronal regions important for cognition and behaviour. Hence, BCHE is potentially an important target for diagnosis and treatment of $\mathrm{AD}$ and is being studied currently. Experimental studies have shown that diminished BCHE activity can prove beneficial in AD. However, it is too early to comment on its therapeutic role in management of $\mathrm{AD}^{[77]}$.

\section{Antioxidants:}

The knowledge that reactive oxygen species plays a major role in the pathogenesis of $\mathrm{AD}$ has led to the use of antioxidants as a treatment strategy. There have been some reports of antioxidants showing some efficacy in few clinical trials, but these studies have not been able to answer whether antioxidants are truly protective against $\mathrm{AD}^{[78,79]}$. A randomized clinical trial has shown that treatment with $\alpha$-tocopherol at a dose of $2000 \mathrm{IU} / \mathrm{d}$ reduces neuronal damage and slows the progression of $\mathrm{AD}$ in patients with moderately severe impairment $^{[79,80]}$.

Homocysteine theory mentions possible role of vitamin $\mathrm{B}$ in cognition and some clinical studies have reported beneficial effects of vitamin B supplementation in $\mathrm{AD}^{[81,82]}$. However, a systematic review published in 2014 showed the evidence is limited and further randomized clinical trials are needed to validate the same $^{[83]}$.

\section{Vitamin D and AD:}

Vitamin D deficiency is linked to neurodegeneration and dementia including that of $\mathrm{AD}^{[84]}$. But therapeutic use of vitamin $\mathrm{D}$ for management of $\mathrm{AD}$ is not yet recommended owing to lack of quality clinical data. Due to limited evidence hypo-vitaminosis D is not yet considered diagnostic or prognostic of $\mathrm{AD}^{[85]}$.

\section{Immunization in AD:}

Immunotherapeutic approaches are being tried for management of AD. Immunization in AD can be divided as active immunization and passive immunization. In the active immunization mode, three peptide vaccines namely CAD106, ACC001, and Affitope, have reported to have entered phase 2 clinical trials ${ }^{[86]}$. These peptide 
vaccines have been modified in such a way to prevent the activation of $\mathrm{T}$ cell but were capable of activating A $\beta$ specific antibodies. Phase 1 trials of these vaccines had reported positive effects ${ }^{[86]}$.

AntiA $\beta$ antibodies, in which pre-formed and manufactured 'humanized antibodies' are injected as passive immunization therapy have also been reported. Solanezumab has failed to show significant result in phase 3 clinical studies, gantenerumab has shown limited benefits in phase 3 studies and crenezumab is in phase 2 clinical studies and have reportedly shown benefits in mild forms of $\mathrm{AD}^{[68,86]}$.

\section{Stem cell therapy:}

Using cell-replacement therapies with human embryonic stem cell or induced pluripotent stem cellderived neural cells to replace dead neurons hold huge potential for treating AD. Recent advances in stem cell research like induced pluripotent stem cell technology, has helped the transformation of such stem cell-derived neural cells into different types of neurons and glial cells in in vivo and animal studies ${ }^{[87]}$. Investigational new drug approval was granted by USFDA in 2015 for the first phase 2A clinical trial of ischemia-tolerant mesenchymal stem cells to treat AD. Similar studies are being planned in Europe and Asia ${ }^{[88]}$. However, it will take a long time to evaluate the therapeutic potential of such therapies.

\section{Combination therapy for AD:}

Most of the chronic diseases use combination therapy to get optimal response with existing therapies. Similar approach is adopted for management of AD. Accelerate Cure/Treatments for Alzheimer's disease Coalition, the Critical Path Institute and the Alzheimer's Association has tried to address the challenges in designing clinical trials to test various treatments in combination. Soon such clinical trials evaluating the combination therapy for management of $\mathrm{AD}$ will be a reality ${ }^{[89]}$.

Cilostazol, an antiplatelet agent with pleiotropic effects based on phosphodiesterase-3-dependent mechanisms was studied for its use in management of $\mathrm{AD}^{[90]}$. A retrospective analysis of cilostazol as an addon therapy in patients with mild dementia receiving donepezil shown to suppress the cognitive decline ${ }^{[0,91]}$. Prospective randomized controlled trials (RCT) are required to validate these results.

\section{Role of traditional medicine:}

In traditional Chinese and Indian medicinal systems, numerous plant products have been used in treating cognitive disorders. Galantamine is one such plant extract used in Chinese medicine ${ }^{[92]}$. It is an alkaloid extracted from several members of the Amaryllis family. It has been found to slow down the process of neurological degeneration in AD. It acts as a weak competitive and reversible cholinesterase inhibitor and as allosteric modulator at nicotinic receptors. Hence, it belongs to class of ACHEI. Six-month treatment with galantamine has shown significant improvement in cognition and global function in a clinical study on 636 patients with mild to moderate $\mathrm{AD}^{[93]}$. Another study in 978 patients with mild to moderate AD has reported significant benefits of galantamine in the cognitive, functional, and behavioural symptoms of $\mathrm{AD}$ as compared with placebo ${ }^{[94]}$. A Cochrane review published in 2006 has showed that galantamine used at the doses above $8 \mathrm{mg} / \mathrm{d}$ showed better results in mild to moderate AD. There are no studies for its use in severe $\mathrm{AD}$. The safety profile was similar to that of $\mathrm{ACHEI}^{[95]}$. In two clinical studies involving 2048 patients with mild cognitive impairment (MCI), galantamine failed to halt the progression of the disease. Total 14 (13 patients receiving galantamine and 1 on placebo) died within $30 \mathrm{~d}$ of discontinuing from the double-blind period (per-protocol assessment) however a posthoc analysis of the cohort has showed no increased risk with galantamine ${ }^{[96]}$. Combination therapy with galantamine $(16 \mathrm{mg})$ with memantine $(20 \mathrm{mg})$ was evaluated in a $2 \mathrm{y}$, double-blinded, placebo-controlled study with $232 \mathrm{MCI}$ patients. The recruitment for this study had to be stopped as results of an intermediate analysis of safety data of two studies on galantamine in MCI as mentioned earlier, showed significant serious adverse events including death. In this interrupted study, short-term combination therapy had shown cognitive benefits ${ }^{[97]}$. A recent study with combination of galantamine and ambulatory cognitive rehabilitation in 86 patients of $\mathrm{AD}$, combination therapy showed superior benefits on cognitive and affective functions than galantamine alone ${ }^{[98]}$. Okayama Galantamine Study (OGS) determined the long-term efficacy of galantamine treatment in older Japanese patients $(80.6 \pm 7.2$ y) with AD. A total of 279 patients were studied for $2 \mathrm{y}$ and found to preserve the cognitive functions till $1 \mathrm{y}$. Subgroup analysis showed better response to galantamine for male and lower baseline function ${ }^{[99]}$.

Panax notoginseng is widely used in traditional Chinese medicine to improve learning and memory. A study has demonstrated the beneficial effect of 
ginsenosides $\mathrm{Rg} 1$ and $\mathrm{Rb} 1$ in a mouse model of $\mathrm{AD}^{[100]}$. Notoginsenoside R1 has been reported to increases neuronal excitability and ameliorates synaptic and memory dysfunction, thereby contributing against neuronal toxicity by $A \beta^{[101]}$. Huperzine $A$ is a natural ACHEI derived from the Chinese herb Huperzia serrata, also acts as a NMDA receptor antagonist. It has antioxidant and neuroprotective properties that suggest its usefulness as a disease-modifying treatment for $\mathrm{AD}^{[102,103]}$. A systematic review and meta-analysis of RCT on huperzine has mentioned 20 clinical studies and showed its beneficial effects on cognitive function, daily living activity, and global clinical assessment in participants with AD. However, it has also highlighted poor methodology in these clinical studies and hence more quality data is needed to substantiate its therapeutic role ${ }^{[104]}$.

Ancient system of medicine in India, the Ayurveda described various herbal formulations named Medhya Rasayana for the management of neurological disorders including $\mathrm{AD}^{[105]}$. Brahmi (Bacopa monnieri) has been used to improve intelligence and memory and this use is studied clinically ${ }^{[106]}$. It has also been found to be effective in rat model of $\mathrm{AD}$ as a potential cognitive enhancer and neuroprotector ${ }^{[107]}$. A meta-analysis of RCTs on Brahmi extracts for their cognitive effects showed its potential to improve cognition, particularly speed of attention. However, its role in management of $\mathrm{AD}$ is questionable due to lack of clinical evidence ${ }^{[108]}$.

Various Ayurvedic herbs like Amla (Phyllanthus emblica), Guduchi (Tinospora cordifolia), Shankhapushpi (Convolvulus pluricaulis), Ashwagandha (Withania somnifera), Tulsi (Ocimum sanctum), Mandukaparni (Centella asiatica) and Haritaki (Terminalia chebula) have been used in the treatment of memory disorders effectively ${ }^{[105-111]}$. Nishteswar et al. has reviewed the use of these indigenous herbs in the management of $\mathrm{AD}$ and highlighted the potential of these herbs ${ }^{[105]}$.

In a proof of concept study done by us in rodents, a combination of $P$. emblica and $T$. cordifolia with Bhavana Samskara (of O. sanctum) showed better results than modern agents like rivastigmine or piracetam on learning and memory parameters ${ }^{[110,111]}$. These drugs are the potential candidates for management of dementia including that of AD though the exact actions of these plants drugs are yet to be explored in clinical studies. Curcumin has been known for ages and used commonly in India as an ingredient of food and cosmetic products. It has antioxidant, antiinflammatory, and platelet aggregation inhibiting properties. It has also been found to have effect on $\mathrm{A} \beta$ aggregation in $\mathrm{AD}$ and currently being investigated in clinical studies ${ }^{[12-114]}$. Resveratrol, a polyphenol from various herbs and red wine with neuroprotective actions has been studied as a potential candidate for the management of AD in pre-clinical studies however, its bioavailability appeared to be a limiting factor ${ }^{[115]}$.

Marine-derived drugs like homotaurine, bryostatin, cytarabine, trabectedin, eribulin, and ziconotide have shown beneficial effects in neurodegenerative diseases, that included $\mathrm{AD}^{[116,117]}$. Some of these drugs have entered clinical studies ${ }^{[116,117]}$. Currently clinical trials evaluating the role of Bry-1 (bryostatin) and homotaurine in management of $\mathrm{AD}$ have been in progress $^{[116,117]}$.

\section{Role of complementary and integrative medicine:}

Integrated approach for management of $\mathrm{AD}$ could be helpful considering the limitations of available treatment options. Dietary or nutritional supplements, yoga, meditation, acupuncture have been reported to benefit in such patients and also used as preventive measures for dementia ${ }^{[118-120]}$. Household spices such as ginger, turmeric, rosemary, sage, cinnamon, salvia herbs are also known to prevent neurodegeneration with the phytochemicals available in them ${ }^{[121]}$. However, the exact mechanisms and overall therapeutic benefits are still unclear and thus no evidence based recommendations exists for their use.

\section{Guidelines:}

Guideline for the treatment of $\mathrm{AD}$ was published by the National Institute on Aging-Alzheimer's Association work-groups on diagnostic guidelines for $\mathrm{AD}$ in the year 2011 ${ }^{[122]}$. The present guideline identifies 3 stages of the disease, with the first starting before symptoms such as, memory loss and before one's ability to carry out everyday activities are affected. It has also highlighted the need to identify biomarkers in the diagnosis of dementia in AD. Biomarkers for level of $\beta$-amyloid accumulation in brain, biomarkers for neuronal injury and degeneration are being suggested to be used in diagnosing $\mathrm{AD}$. The guidelines plan to catch the disease at an early onset and thereby initiate therapy to limit the progression of the disease ${ }^{[122]}$.

California workgroup on guidelines for $\mathrm{AD}$ Management had released an updated report in 2008, which updated and expanded the previous AD 
management guidelines given in $2002^{[23]}$. The report specified the following recommendations: assessment, monitor changes, reassess frequently, identify support, identify culture and values and assess capacity. The treatment in this guideline included: develop a treatment plan, treat behavioural symptoms, nonpharmacological treatment, treat comorbid conditions and provide end-of-life care.

Currently there are no specific guidelines in India for treatment of AD. Even though the prevalence of dementia is low in India compared to western countries, it is estimated at about 4.1 million $^{[4]}$. The age-adjusted incidence rate is estimated at 9.19 per 1000 personyears in 2012 and higher incidence is found with increasing age ${ }^{[7]}$. This number is expected to rise in the near future as reported by Mathuranath et al. ${ }^{[7]}$. A high prevalence of smoking, epidemic of diabetes along with lifestyle changes can have a great effect in the development of the disease and can cause an explosion in the prevalence of AD in India. Dementia care extends beyond providing just the drug therapy to the patient, as it has a social dimension to it and includes the care at family and community levels. People in India do not differentiate between normal ageing process and phenomena or symptoms that are secondary to conditions like dementia. In these circumstances an India specific guideline will be of great help for the care givers and for the patients' families ${ }^{[123]}$.

$\mathrm{AD}$ pathogenesis is a complex process involving both genetic and environmental factors. Current pharmacotherapy of $\mathrm{AD}$ relies on the symptomatic effects of anticholinesterases and NMDA-receptor antagonists; it does not target the disease process. Therefore development of effective disease-modifying drugs is proving to be a difficult task. Current pharmacotherapy is not sufficient to halt the disease progression. $\mathrm{A} \beta, \tau$ and metals are few of the important therapeutic targets identified and compounds that modulate them represent promising drug candidates. Ayurveda have some promising agents to be evaluated in clinical trials for the management of AD. Evidence with alternate therapies is limited and robust clinical data is lacking. Thus, further research is needed to evaluate if integrated approach of combining the existing therapies, traditional medicines and newer treatments can improve the care for patients with AD. Considering the disease burden in India, the clinicians need a specific guidance on the management strategies for AD. This review should help readers to make an informed choice for managing $\mathrm{AD}$ from the available options.

\section{Financial support and sponsorship:}

Nil.

\section{REFERENCES}

1. Desimone R. The physiology of memory: recordings of things past. Science 1992;258:245-6.

2. Baddeley AD. Essentials of Human Memory. Cambridge (MA), Bristol (UK): Psychology Press Ltd.; 1999.

3. Aprahamian I, Stella F, Forlenza OV. New treatment strategies for Alzheimer's disease: is there a hope? Indian J Med Res 2013;138:449-60.

4. http://www.alz.co.uk/research/WorldAlzheimerReport2015. pdf.

5. Alzheimer's Association. Alzheimer's disease facts and figures. Alzheimer's Dement 2015;11:332-84.

6. Shaji KS, Jithu VP, Jyothi KS. Indian research on aging and dementia. Indian J Psychiatry 2010;52:148-52.

7. Mathuranath PS, George A, Ranjith N, Justus S, Kumar MS, Menon R, et al. Incidence of Alzheimer's disease in India: a 10 years' follow-up study. Neurol India 2012;60:625-30.

8. Ferri CP, Prince M, Brayne C, Brodaty H, Fratiglioni L, Ganguli M, et al. Global prevalence of dementia: a Delphi consensus study. Lancet 2005;366:2112-7.

9. Hippius H, Neundörfer G. The discovery of Alzheimer's disease. Dialogues Clin Neurosci 2003;5:101-8.

10. Plum F. The pathophysiology of dementia. Gerontology 1986;32:67-72.

11. Jalbert JJ, Daiello LA, Lapane KL. Dementia of the Alzheimer type. Epidemiol Rev 2008;30:15-34.

12. Haas C. Strategies, development, and pitfalls of therapeutic options for Alzheimer's disease. J Alzheimers Dis 2012;28:241-81.

13. Herrup K. The case for rejecting the amyloid cascade hypothesis. Nat Neurosci 2015;18:794-9.

14. Bush AI, Tanzi RE. Therapeutics for Alzheimer's disease based on the metal hypothesis. Neurotherapeutics 2008;5:42132.

15. Prakash A, Dhaliwal GK, Kumar P, Majeed AB. Brain Biometals and Alzheimer's Disease - Boon or Bane? Int J Neurosci 2016:1-34.

16. Lindsay J, Laurin D, Verreault R, Hébert R, Helliwell B, Hill GB, et al. Risk Factors for Alzheimer's Disease: A Prospective Analysis from the Canadian Study of Health and Aging. Am J Epidemiol 2002;156:445-53.

17. Kesner RP. Reevaluation of the contribution of the basal forebrain cholinergic system to memory. Neurobiol Aging 1988;9:609-16.

18. Cummings JL, Kaufer D. Neuropsychiatric aspects of Alzheimer's disease: the cholinergic hypothesis revisited. Neurology 1996;47:876-83.

19. Stampfer MJ. Cardiovascular disease and Alzheimer's disease: common links. J Intern Med 2006;260:211-23.

20. Luchsinger JA, Mayeux R. Cardiovascular risk factors and Alzheimer's disease. Curr Atheroscler Rep 2004;6:261-6.

21. Mosconi L, Sorbi S, Nacmias B, De Cristofaro MT, Fayyaz M, Cellini E, et al. Brain metabolic differences between sporadic and familial Alzheimer's disease. Neurology 2003;61:113840 . 
22. Piaceri I, Nacmias B, Sorbi S. Genetics of familial and sporadic Alzheimer's disease. Front Biosci 2013;5:167-77.

23. Segal-Gidan F, Cherry D, Jones R, Williams B, Hewett L, Chodosh J. California Workgroup on Guidelines for Alzheimer's disease Management. Guideline for Alzheimer's disease Management. Alzheimers Dement 2011;7:e51-9.

24. Mayeux R, Sano M. Treatment of Alzheimer's disease. N Engl J Med 1999;341:1670-9.

25. Winslow BT, Onysko MK, Stob CM, Hazlewood KA. Treatment of Alzheimer Disease. Am Fam Physician 2011;83:1403-12.

26. Leonard BE. Pharmacotherapy in the treatment of Alzheimer's disease: an update. World Psychiatry 2004;3:84-8.

27. Birks JS, Grimley EJ. Rivastigmine for Alzheimer's disease. Cochrane Database Syst Rev 2015;4:CD001191.

28. Birks J, Harvey RJ. Donepezil for dementia due to Alzheimer's disease. Cochrane Database Syst Rev 2006;1:CD001190.

29. Cummings JL, Isaacson RS, Schmitt FA, Velting DM. A practical algorithm for managing Alzheimer's disease: what, when, and why? Ann Clin Transl Neurol 2015;2:307-23.

30. Buckley JS, Salpeter SR. A Risk-Benefit Assessment of Dementia Medications: Systematic Review of the Evidence. Drugs Aging 2015;32:453-67.

31. Johnson JW, Kotermanski SE. Mechanism of action of memantine. Curr Opin Pharmacol 2006;6:61-7.

32. Olivares D, Deshpande VK, Shi Y, Lahiri DK, Greig NH, Rogers JT, et al. N-methyl D-aspartate (NMDA) receptor antagonists and memantine treatment for Alzheimer's disease, vascular dementia and Parkinson's disease. Curr Alzheimer Res 2012;9:746-58.

33. Patel L, Grossberg GT. Combination therapy for Alzheimer's disease. Drugs Aging 2011;28:539-46.

34. Claus JJ, Ludwig C, Mohr E, Giuffra M, Blin J, Chase TN. Nootropic drugs in Alzheimer's disease: symptomatic treatment with pramiracetam. Neurology 1991;41:570-4.

35. Croisile B, Trillet M, Fondarai J, Laurent B, Mauguière F, Billardon M. Long-term and high-dose piracetam treatment of Alzheimer's disease. Neurology 1993;43:301-5.

36. Flicker L, Grimley Evans G. Piracetam for dementia or cognitive impairment. Cochrane Database Syst Rev 2001;2:CD001011.

37. Sanchez PE, Zhu L, Verret L, Vossel KA, Orr AG, Cirrito JR, et al. Levetiracetam suppresses neuronal network dysfunction and reverses synaptic and cognitive deficits in an Alzheimer's disease model. Proc Natl Acad Sci U S A 2012;109:E2895903.

38. Sachdeva D, Burns A. Dimebolin in dementia. CNS Neurosci Ther 2011;17:199-205.

39. Webster SJ, Wilson CA, Lee C-H, Mohler EG, Terry AV Jr, Buccafusco JJ. The acute effects of dimebolin, a potential Alzheimer's disease treatment, on working memory in rhesus monkeys. Br J Pharmacol 2011;164:970-8.

40. Chau S, Herrmann N, Ruthirakuhan MT, Chen JJ, Lanctôt KL. Latrepirdine for Alzheimer's disease. Cochrane Database Syst Rev 2015;4:CD009524.

41. Zhao L, Woody S, Chhibber A. Estrogen receptor $\beta$ in Alzheimer's disease: From mechanisms to therapeutics. Ageing Res Rev 2015;24:1787-90.

42. Nathan L, Chaudhuri G. Antioxidant and pro-oxidant actions of estrogens: potential physiological and clinical implications. Semin Reprod Endocrinol 1998;16:309-14.
43. Daneschvar HL, Aronson MD, Smetana GW. Do statins prevent Alzheimer's disease? A narrative review. Eur J Intern Med 2015;26:666-9.

44. McGuinness B, Passmore P. Can statins prevent or help treat Alzheimer's disease? J Alzheimers Dis 2010;20:925-33.

45. Haag MDM, Hofman A, Koudstaal PJ, Stricker BHC, Breteler MMB. Statins are associated with a reduced risk of Alzheimer disease regardless of lipophilicity. The Rotterdam Study. J Neurol Neurosurg Psychiatry 2009;80:13-7.

46. McGuinness B, Craig D, Bullock R, Malouf R, Passmore P. Statins for the treatment of dementia. Cochrane Database Syst Rev 2014;7:CD007514.

47. McGeer PL, McGeer EG. NSAIDs and Alzheimer disease: epidemiological, animal model and clinical studies. Neurobiol Aging 2007;28:639-47.

48. Beard CM, Waring SC, O'Brien PC, Kurland LT, Kokmen E. Nonsteroidal antiinflammatory drug use and Alzheimer's disease: a case-control study in Rochester, Minnesota, 1980 through 1984. Mayo Clin Proc 1998;73:951-5.

49. Vlad SC, Miller DR, Kowall NW, Felson DT. Protective effects of NSAIDs on the development of Alzheimer disease. Neurology 2008;70:1672-7.

50. Jaturapatporn D, Isaac MG, McCleery J, Tabet N. Aspirin, steroidal and non-steroidal antiinflammatory drugs for the treatment of Alzheimer's disease. Cochrane Database Syst Rev 2012;2:CD006378.

51. Wang J, Tan L, Wang HF, Tan CC, Meng XF, Wang C, et al. Antiinflammatory drugs and risk of Alzheimer's disease: an updated systematic review and meta-analysis. J Alzheimer's Dis 2015;44:385-96.

52. Vigen CLP, Mack WJ, Keefe RSE, Sano M, Sultzer DL, Stroup TS, et al. Cognitive effects of atypical antipsychotic medications in patients with Alzheimer's disease: outcomes from CATIE-AD. Am J Psychiatry 2011;168:831-9.

53. Pasqualetti G, Tognini S, Calsolaro V, Polini A, Monzani F. Potential drug-drug interactions in Alzheimer patients with behavioral symptoms. Clin Interv Aging 2015; 10:1457-66.

54. Ballard C, Khan Z, Clack H, Corbett A. Non-pharmacological treatment of Alzheimer's disease. Can J Psychiatry 2011;56:589-95.

55. Oken BS, Storzbach DM, Kaye JA. The efficacy of Ginkgo biloba on cognitive function in Alzheimer's disease. Arch Neurol 1998;55:1409-15.

56. Smith JV, Luo Y. Elevation of oxidative free radicals in Alzheimer's disease models can be attenuated by Ginkgo biloba extract EGb 761. J Alzheimer's Dis 2003;5:287-300.

57. Janssen IM, Sturtz S, Skipka G, Zentner A, Velasco Garrido M, Busse R. Ginkgo biloba in Alzheimer's disease: a systematic review. Wien Med Wochenschr 2010;160:539-46.

58. Canevelli M, Adali N, Kelaiditi E, Cantet C, Ousset PJ, Cesari M. Effects of Gingko biloba supplementation in Alzheimer's disease patients receiving cholinesterase inhibitors: data from the ICTUS study. Phytomedicine 2014;21:888-92.

59. Yang M, Xu DD, Zhang Y, Liu X, Hoeven R, Cho WC. A systematic review on natural medicines for the prevention and treatment of Alzheimer's disease with meta-analyses of intervention effect of ginkgo. Am J Chin Med 2014;42:50521.

60. Biran Y, Masters CL, Barnham KJ, Bush AI, Adlard PA. Pharmacotherapeutic targets in Alzheimer's disease. J Cell Mol Med 2009;13:61-86.

61. Salomone S, Caraci F, Leggio GM, Fedotova J, Drago F. 
New pharmacological strategies for treatment of Alzheimer's disease: focus on disease modifying drugs. Br J Clin Pharmacol 2012;73:504-17.

62. Kumar A, Singh A, Ekavali. A review on Alzheimer's disease pathophysiology and its management: an update. Pharmacol Rep 2015;67:195-203.

63. Kumar A, Nisha CM, Silakari C, Sharma I, Anusha K, Gupta $\mathrm{N}$, et al. Current and novel therapeutic molecules and targets in Alzheimer's disease. J Formos Med Assoc 2015;115:3-10.

64. Anand R, Gill KD, Mahdi AA. Therapeutics of Alzheimer's disease: Past, present and future. Neuropharmacology 2014;76:27-50.

65. Ginter E, Simko V, Weinrebova D, Ladecka Z. Novel potential for the management of Alzheimer disease. Bratisl Lek Listy 2015;116:580-1.

66. Bloom GS. Amyloid- $\beta$ and tau: the trigger and bullet in Alzheimer disease pathogenesis. JAMA Neurol 2014;71:505-8.

67. Wischik CM, Harrington CR, Storey JM. Tau-aggregation inhibitor therapy for Alzheimer's disease. Biochem Pharmacol 2014;88:529-39.

68. Zhao LN, Lu L, Chew LY, Mu Y. Alzheimer's disease-a panorama glimpse. Int J MolSci 2014;15:12631-50.

69. Ehret MJ, Chamberlin KW. Current Practices in the Treatment of Alzheimer Disease: Where is the Evidence After the Phase III Trials? Clin Ther 2015;37:1604-16.

70. Galimberti D, Scarpini E. Disease-modifying treatments for Alzheimer's disease. Ther Adv Neurol Disord 2011;4:203-16.

71. Gervais F, Chalifour R, Garceau D, Kong X, Laurin J, Mclaughlin R, et al. Glycosaminoglycan mimetics: a therapeutic approach to cerebral amyloid angiopathy. Amyloid 2001;8:28-35.

72. Dodel R, Neff F, Noelker C, Pul R, Du Y, Bacher M, et al. Intravenous immunoglobulins as a treatment for Alzheimer's disease: rationale and current evidence. Drugs 2010;70:51328.

73. Geldenhuys WJ, Darvesh AS. Pharmacotherapy of Alzheimer's disease: current and future trends. Expert Rev Neurother 2015;15:3-5.

74. Christen Y. Oxidative stress and Alzheimer disease. Am J Clin Nutr 2000;71:621S-29S.

75. Ebadi M, Brown-Borg H, Ren J, Sharma S, Shavali S, El ReFaey $\mathrm{H}$, et al. Therapeutic efficacy of selegiline in neurodegenerative disorders and neurological diseases. Curr Drug Targets 2006;7:1513-29.

76. Weinreb O, Amit T, Bar-Am O, Youdim MB. Ladostigil: a novel multimodal neuroprotective drug with cholinesterase and brain-selective monoamine oxidase inhibitory activities for Alzheimer's disease treatment. Curr Drug Targets 2012;13:483-94.

77. Darvesh S. Butyryl-cholinesterase as a Diagnostic and Therapeutic Target for Alzheimer's disease. Curr Alzheimer Res 2016;13:1173-7.

78. Gilgun-Sherki Y, Melamed E, Offen D. Antioxidant treatment in Alzheimer's disease: current state. J Mol Neurosci 2003;21:1-11.

79. Cervellati C, Wood PL, Romani A, Valacchi G, Squerzanti $\mathrm{M}$, Sanz JM, et al. Oxidative challenge in Alzheimer's disease: state of knowledge and future needs. J Investig Med 2016;64:21-32.

80. Sano M, Ernesto C, Thomas RG, Klauber MR, Schafer $\mathrm{K}$, Grundman $\mathrm{M}$, et al. A controlled trial of Selegiline, $\alpha$-tocopherol, or both as treatment for Alzheimer's disease. $\mathrm{N}$ Engl J Med 1997;336:1216-22.

81. Morris MS. The role of B vitamins in preventing and treating cognitive impairment and decline. Adv Nutr 2012;3:801-12.

82. Feng Y, Wang X. Antioxidant therapies for Alzheimer's disease. Oxid Med Cell Longev 2012;2012:472-932.

83. Li MM, Yu JT, Wang HF, Jiang T, Wang J, Meng XF, et al. Efficacy of vitamin B supplementation on mild cognitive impairment and Alzheimer's disease: a systematic review and meta-analysis. Curr Alzheimer Res 2014;11:844-52.

84. Keeney JT, Butterfield DA. Vitamin D deficiency and Alzheimer disease: Common links. Neurobiol Dis 2015;84:8498.

85. Banerjee A, Khemka VK, Ganguly A, Roy D, Ganguly U, Chakrabarti S. Vitamin D and Alzheimer's Disease: Neurocognition to Therapeutics. Int $\mathrm{J}$ Alzheimers Dis 2015;2015:192747.

86. Lambracht-Washington D, Rosenberg RN. Advances in the development of vaccines for Alzheimer's disease. Discov Med 2013;15:319-26.

87. Tong LM, Fong H, Huang Y. Stem cell therapy for Alzheimer's disease and related disorders: current status and future perspectives. Exp Mol Med 2015;47:e151.

88. Hunsberger JG, Rao M, Kurtzberg J, Bulte JW, Atala A, LaFerla FM, et al. Accelerating stem cell trials for Alzheimer's disease. Lancet Neurol 2015;S1474-4422(15)00332-4.

89. Perry D, Sperling R, Katz R, Berry D, Dilts D, Hanna D, et al. Building a roadmap for developing combination therapies for Alzheimer's disease. Expert Rev Neurother 2015;15:327-33.

90. Ihara M, Nishino M, Taguchi A, Yamamoto Y, Hattori Y, Saito $\mathrm{S}$, et al. Cilostazol add-on therapy in patients with mild dementia receiving donepezil: a retrospective study. PLoS One 2014;9:e89516.

91. Taguchi A, Takata Y, Ihara M, Kasahara Y, Tsuji M, Nishino $\mathrm{M}$, et al. Cilostazol improves cognitive function in patients with mild cognitive impairment: a retrospective analysis. Psychogeriatrics 2013;13:164-9.

92. Howes MJ, Houghton PJ. Plants used in Chinese and Indian traditional medicine for improvement of memory and cognitive function. Pharmacol Biochem Behav 2003;75:513-27.

93. Raskind MA, Peskind ER, Wessel T, Yuan W. Galantamine in $\mathrm{AD}$ a 6-month randomized, placebo-controlled trial with a 6-month extension. The Galantamine USA-1 Study Group. Neurology 2000;54:2261-8.

94. Tariot PN, Solomon PR, Morris JC, Kershaw P, Lilienfeld S, Ding C. A 5-month, randomized, placebo-controlled trial of galantamine in AD. The Galantamine USA-10 Study Group. Neurology 2000;54:2269-76.

95. Loy C, Schneider L. Galantamine for Alzheimer's disease and mild cognitive impairment. Cochrane Database Syst Rev 2006;1:CD001747.

96. Winblad B, Gauthier S, Scinto L, Feldman H, Wilcock GK, Truyen L, et al. GAL-int-11/18 study Group. Safety and efficacy of galantamine in subjects with mild cognitive impairment. Neurology 2008;70:2024-35.

97. Peters O, Lorenz D, Fesche A, Schmidtke K, Hüll M, Perneczky $\mathrm{R}$, et al. A combination of galantamine and memantine modifies cognitive function in subjects with amnestic MCI. J Nutr Health Aging 2012;16:544-8.

98. Tokuchi R, Hishikawa N, Matsuzono K, Takao Y, Wakutani Y, Sato $\mathrm{K}$, et al. Cognitive and affective benefits of combination 
therapy with galantamine plus cognitive rehabilitation for Alzheimer's disease. Geriatr Gerontol Int 2016;16:440-5.

99. Nakano Y, Matsuzono K, Yamashita T, Ohta Y, Hishikawa $\mathrm{N}$, Sato $\mathrm{K}$, et al. Long-Term Efficacy of Galantamine in Alzheimer's Disease: The Okayama Galantamine Study (OGS). J Alzheimers Dis 2015;47:609-17.

100. Li N, Zhou L, Li W, Liu Y, Wang J, He P. Protective effects of ginsenosides Rg1 and Rb1 on an Alzheimer's disease mouse model: a metabolomics study. J Chromatogr B Analyt Technol Biomed Life Sci 2015;985:54-61.

101. Yan S, Li Z, Li H, Arancio O, Zhang W. Notoginsenoside R1 increases neuronal excitability and ameliorates synaptic and memory dysfunction following amyloid elevation. Sci Rep 2014;4:6352.

102. Wang R, Yan H, Tang X-C. Progress in studies of huperzine $A$, a natural cholinesterase inhibitor from Chinese herbal medicine. Acta Pharmacol Sin 2006;27:1-26.

103. Li J, Wu HM, Zhou RL, Liu GJ, Dong BR. Huperzine A for Alzheimer's disease. Cochrane Database Syst Rev 2008;2:CD005592.

104. Yang G, Wang Y, Tian J, Liu JP. Huperzine A for Alzheimer's disease: a systematic review and meta-analysis of randomized clinical trials. PLoS One 2013;8:e74916.

105. Nishteswar K, Joshi H, Karra RD. Role of indigenous herbs in the management of Alzheimer's disease. Anc Sci Life 2014;34:3-7.

106. Roodenrys S, Booth D, Bulzomi S, Phipps A, Micallef C, Smoker J. Chronic Effects of Brahmi (Bacopa monnieri) on Human Memory. Neuropsychopharmacology 2002;27:27981.

107. Uabundit N, Wattanathorn J, Mucimapura S, Ingkaninan K. Cognitive enhancement and neuroprotective effects of Bacopa monnieri in Alzheimer's disease model. J Ethnopharmacol 2010;127:26-31.

108. Kongkeaw C, Dilokthornsakul P, Thanarangsarit $\mathrm{P}$, Limpeanchob N, Scholfield NC. Meta-analysis of randomized controlled trials on cognitive effects of Bacopa monnieri extract. J Ethnopharmacol 2014;151:528-35.

109. Kuboyama T, Tohda C, Komatsu K. Effects of Ashwagandha (roots of Withania somnifera) on neurodegenerative diseases. Biol Pharm Bull 2014;37:892-7.

110. Malve HO, Raut SB, Marathe PA, Rege NN. Effect of combination of Phyllanthus emblica, Tinospora cordifolia, and Ocimum sanctum on spatial learning and memory in rats. J Ayurveda Integr Med 2014;5:209-15.

111. Malve HO. Exploring Bhavana samskara using Tinospora cordifolia and Phyllanthus emblica combination for learning and memory in mice. J Ayurveda Integr Med 2015;6:233-40.

112. Ringman JM, Frautschy SA, Cole GM, Masterman DL, Cummings JL. A potential role of the curry spice curcumin in Alzheimer's disease. Curr Alzheimer Res 2005;2:131-6.

113. Venigalla M, Gyengesi E, Münch G. Curcumin and Apigenin - novel and promising therapeutics against chronic neuroinflammation in Alzheimer's disease. Neural Regen Res 2015;10:1181-5.

114. Mishra S, Palanivelu K. The effect of curcumin (turmeric) on Alzheimer's disease: An overview. Ann Indian Acad Neurol 2008;11:13-9.

115. Ma T, Tan MS, Yu JT, Tan L. Resveratrol as a therapeutic agent for Alzheimer's disease. Biomed Res Int 2014;2014:350516.

116. Russo P, Kisialiou A, Lamonaca P, Moroni R, Prinzi G, Fini M. New Drugs from Marine Organisms in Alzheimer's Disease. Mar Drugs 2015;14:E5.

117. Malve H. Exploring the ocean for new drug developments: Marine pharmacology. J Pharm Bioall Sci 2016;8:83-91.

118. Ashford WJ, Mahoney L, Burkett T. A Role for Complementary and Integrative Medicine in Alzheimer's disease Prevention. J Alzheimers Dis 2015;48:13-4.

119. Foster PP. Role of physical and mental training in brain network configuration. Front Aging Neurosci 2015;7:117.

120. McCaffrey R, Park J, Newman D, Hagen D. The effect of chair yoga in older adults with moderate and severe Alzheimer's disease. Res Gerontol Nurs 2014;7:171-7.

121. Hügel HM. Brain Food for Alzheimer-Free Ageing: Focus on Herbal Medicines. Adv Exp Med Biol 2015;863:95-116.

122. McKhann GM, Knopman DS, Chertkow H, Hyman BT, Jack CR Jr, Kawas $\mathrm{CH}$, et al. The diagnosis of dementia due to Alzheimer's disease: recommendations from the National Institute on Aging-Alzheimer's Association workgroups on diagnostic guidelines for Alzheimer's disease. Alzheimers Dement 2011;7:263-9.

123. Shaji KS, Jotheeswaran AT, Girish N, Bharath S, Dias A, Pattabiraman M, et al. The dementia India report 2010. Alzheimer's and Related Disorders Society of India, New Delhi; 2010. 